\title{
P-30 HIGH RESOLUTION SEQUENCE STRATIGRAPHY OF A NUMMULITIC CARBONATE SYSTEM, YPRESIAN, JEBEL OUSSELAT, CENTRAL TUNISIA
}

E. VENNIN', F. VAN BUCHEM ${ }^{2}, M$. SONNENFELD ${ }^{3}$, P. JOSEPH ${ }^{2}$, M. REBELLE

'MNHN, Lab. de Géologie, 43 Rue Buffon, 75005 Paris, France institute Français du Pétrole 'Elf Exploration-Production

\begin{abstract}
The Ypresian rocks of northern Africa constitute one of the main carbonate systems with hydrocarbon accumulation in Tunisia and Lybia. The reservoir facies of outcrops of the Jebel Ousselat area are formed by the nummulitic-dominated shallow-water carbonates of the El Garia Formation. Reservoir rock facies have been studied in outcrop (Comte \& Lehmann 1974; Fournié 1975; Elloy 1985; Fakhfakh 1989; Homewood \& Van Buchem 1992; Van der Pijl \& Point 1993) and subsurface (Elloy 1979; Saint Marc 1992; Homewood 1993; Mahjoub 199394). These previous works envisaged sedimentological studies and sequence stratigraphic works at kilometre scale.
\end{abstract}

This study presents a high resolution sequence stratigraphic model for this interval, that enables, (1) a geometrical reconstruction of the depositional system constrained by timelines, (2) a definition of lateral facies changes within depositional sequences, and (3) an assessment of the position of the nummulites within this framework.

The El Garia Formation crops out in the eastern and western flanks of the Jebel Ousselat and in the Jebels Es Sfeia and Kef el Garia, which are located at $40 \mathrm{~km}$ in the northeast of Kairouan (Tunisia). In response to a distentional E-W history of the study area, several large basins of the Thetysian marge were developed from the Jurassic to Lower Miocene times (Bishop, 1988). Tectonic movements induced the development of topographic highs and low's, which affected sedimentary architecture.

The Lower Eocene succession shows a nummulitic and carbonate-dominant character. The El Garia Formation (Ypresian age) is underlain by the Choubine Formation, and overlain by the Cherahil Formation (Bishop, 1988), and corresponds to laterally age-equivalent formations, such as the Bou Dabbous Formation in northern Tunisia and the Faid and Ain Merhotta Formations in southern Tunisia.

In the Jebel Ousselat area and immediate surroundings (J.Sfeia, J.Jebel) an almost undeformed Nummulitic carbonate ramp system of oil field dimensions ( $3 \mathrm{~km}$ long-10 km large$200 \mathrm{~m}$ high) is exposed in a network of valleys. These outcrop conditions allow surfaces and bedding planes to be physically traced, guaranteeing a robust stratigraphic correlation scheme. The proposed stratigraphic model is based on 14 sedimentological fieldsections, the analysis of 500 thin sections and photomosaic interpretation. 
Seven nummulitic sedimentary systems have been identified in the studied jebels by their facies arrangement and bounding süräcès: "A" mapping 'of nümmulitic systems provide documentation of changing thickness and outcrops conditions.

Twelve facies are distinguished from distal to proximal. Eleven facies correspond to the intrashelf carbonate setting and the last one to a siliciclastic coastal plain. Sedimentary environments are divided into (1) basin, (2) upper offshore-distal shoal margin, (3) upper offshore or nummulitic bioaccumulation, (4) lower shoreface-shoal, and (5) coastal plain.

(1) Basin environments: two main facies associations of intra-shelf basin are distinguished, which are arranged as shale facies and limestone/shale couplets. Limestones of couplets vary in thickness from 0.1 to $1 \mathrm{~m}$ and are composed of nummulitoclasts immerged in micrite matrix. Shales are structureless and contain a diverse biota including nautiloids, sponges, planctonic foraminifera and vertebrate debris. This facies association shows great similarities with the Bou Dabbous Formation described in northern Tunisia.

(2) Upper offshore-distal shoal margin: five facies are associated in this environment and are composed of nummulitoclastic packstones and rare nummulitic floatstones. The outcrops vary from well-bedded limestones in the relatively distal position to metre-scale bedded limestones in proximal position.

(3) Upper offshore-bioaccumulation: three facies are distinguished by their faunistic association which are arranged, from distal to proximal environments, as follows : (a) discocyclinenummulite associations, (b) flat and elongate nummulite forms, and (c) small nummulites associated with thick and rounded nummulitic forms.

(4) Proximal shoal- shoreface environment: four facies are associated in this environment, three of which correspond to floatstones to rudstones facies (containing nummulites and nummulitoclasts) and the last one is a grainstone composed exclusively of nummulitoclasts. Bedding pattern and sedimentary structures evidence high energy conditions. The increase of micritic matrix and scarceness of bioclasts indicate a more restricted and low energy conditions.

(5) Proximal coastal plain: the El Garia Formation is composed in the more eastern and proximal area of calcarenites arranged in cross-bedded channel deposits of coastal plain origin.

Seven $4^{\text {th }}$ order sequences (tens of meters thick) have been recognised, each of these are composed of a least two orders of higher frequency cycles. Cycle expression is best in the distal domain, whereas cycles tend to amalgamate and lack facies offset in the more proximal nummulitic facies. The $4^{\text {th }}$ order sequences show an organised stratigraphic pattern from progradation, to aggradation, to a distinct retrogradation at the top. Within the $4^{\text {th }}$ order sequences rapid lateral facies changes have been observed in a N-S direction. Over a distance of $500 \mathrm{~m}$, facies change from coarse Nummulitic Grainstone/Packstone to Nummulitic debris Packstone-to Wackestone-to organic-rich lime mudstone. A similarity in facies order and geometrical aspects is apparent between both western and eastern area of the jebel Ousselat.

In a E-W direction similar facies changes are observed in a basinward direction, while in the most proximal position, to the East, nearly pure quartz sandstones are found to interfinger with the carbonate deposits. This correlation permit to establish a palaeogeographical model for the Ypresian platform. A similarity in geometrical aspects is apparent between all the sections. However facies change from silicicoclastic dominated in the jebel Sfeia area to carbonate dominant in the Kef el Garia. The jebel Sfeia (50 m thickness) is composed of sandstones, in which dominated in cross-bedded deposits. A coastal plain setting is interpreted for these deposits which took place throughout a regressive trend. Evidence for retrogradation is found in this section where coastal plain conditions pass to carbonate shoreface environment. The Kef el Garia ( $40 \mathrm{~m}$ thickness) profil is composed of nummilitic shoal devoid of silicicoclastic 
components. The variation in thickness recorded between the jebels evidences relative influence of tectonism on the sedimentary pattern as proposed by Van der Pijl \& Point (1993).

The geometry of the entire system can be described as a large scale sismoidal wedge (in a NS and EW direction), prograding away from a paleohigh. Much of this may be predepositional origin, and may have been enhanced during depositional by local syn-sedimentary salt tectonics. At the sight of these correlations, a new model of nummulite biostrome distribution is proposed for this area. Nummulite biostrome develop during the El Garia Formation in basin border. The nummulitic lens show a maximum thickness of $150 \mathrm{~m}$ in the Kef el Guitoune section. To a N-S Ypresian platform/basin polarity is added an E-W one due to the graben evidence. Basin facies appear to the north of Ypresian platform and locally in the jebel Djebil area. The depocenter is characterised by nummulitoclast-rich carbonate/marl couplets similar with the Bou Dabbous facies of the Ypresien basin.

Large benthic forams are primarily represented by different Nummulitic species and Discocyclines. They occur preferentially in the transgressive parts of four. $5^{\text {th }}$ order sequences of each six $4^{\text {th }}$ order sequence. This would characterise them as « r-type » species colonising newly created ecological niches during sea level rise phases. Some elements of intraspecific significance seem to be indicative of depth. Morphological change in shell shape can be consider as an evolutionary adaptation or as a phenotypic response to environmental conditions (Hottinger 1997). Hence, some variations in shape may be indicative of change in accommodation space. Field observations made on Eocene deposits, independently of sequence study, confirmed the correlation of populations of thin lenticular nummulites with times of increasing accommodation. These nummulites are associated with discocyclines in biostromes. In contrast, the population of thick ovoid-shaped nummulites confirmed the correlation with times of decreasing accommodation space. The same morphological changes correlated with accommodation concerns disocyclines; thin and lenticular shapes indicate times of increasing accommodation, whereas thickest and ovoid shapes accompanied megalospheric nummulites in times of decreasing accommodation.

The implications of this work for subsurface studies are : (1) a model for the Ypresian carbonate system is provided which is predictive with regard to the distribution of reservoir. Facies heterogeneities correspond to mudstone and marls in basinward direction and cementedgrainstone in more proximal area of platform. Potential reservoir facies are found in the nummulitic biostrome. The decametre thick package during aggradation and the metre scale shallowing-upward cycles of progradation represent the main reservoir for the El Garia Formation. (2) the high resolution framework permits the definition of lateral variability of facies, their geometries and heterogeneities. And (3) the discussion of palaeoecological significance of shallow benthic foraminiferal assemblages provide a conceptual model to guide the high resolution framework.

References

Bishop W.F. (1988) - Petroleum geology of East-Central Tunisia.- AAPG Bull. 72, 9, 10331085 .

Comte D. \& Lehman P. (1974) - Sur les carbonates de l'Yprésien et du Lutétien basal de la Tunisie Centrale.- Compagnie Français des Pétroles, Notes et Mémoires 11, 275-292.

Elloy R. (1979) - Essai d'interprétation sédimentaire et pétrographique du réservoir d'Ashtart (offshore Tunisien) au travers des puits Ash.- SNEA (P), D.G.P.- D. Explor., Lab. Géol. Pau, 79/04.

Fakhfakh-Ben Jemia H (1989) - « Les calcaires de l'Eocène inféricur en Tunisie CentroSeptentrionale : sédimentologie-paléontologie ». Thèse à l'Université de Franche-Comté en Sciences de la Terre, 1991 ( $n^{\circ} 232$ ).

Fournié D. (1975) - L'analyse séquentielle et la sédimentation de l'Yprésien de Tunisie.- Bull. Cent. Rech. Pau, SNPA 9, 1, 27-75. 
Homewood P. \& Van Buchem F (1992) - Stratigraphie séquentielle de l'Yprésien du gisement d'Ashtart.- Note interne, Elf-Pau.

Homewood P (1993) - "Ashart- principaux résultats - version finale », note technique - Annexe 22, in Calatayud (1994) : „Champ d'Ashtart - modèle géologique 3D. D. Explo, S.N.E.A.P., 12.

Hottinger L. (1997) - Shallow benthic foraminiferal assemblages as signals for depth of deposition and their limitations.- Bull. Soc. Géol. France 168, 4, 491-505.

Mahjoub M.N. (1993) - Etude sédimentologique et diagénétique du réservoir d'Ashtart. $D$. Explo. SEREPT, Tunisie, 30p. Mahjoub M.N. (1993) - Etude sédimentologique et diagénétique du réservoir d'Ashtart. D. Explo. SEREPT, Tunisie, 30p.

Mahjoub M.N. (1994) - Zonation de la formation El Garia dans la région de Kairouanapplication au champ d'Ashtart (aspect qualitatif et quantitatif). D. Explo. SEREPT, Tunisie, 30p.

Pijl van der A. \& Point O. (1993) - Stratigraphie séquentielle des calcaires à nummulites de l'Yprésien (Éocène) de Tunisie.- Rapport ENSPM-Elf Aquitaine Production, Réf. I.F.P. 40998,30 p.

Saint-Marc. P. (1992a) - Biogeographic and bathymetric distribution of benthic foraminifera in Paleocene El Haria Formation of Tunisia.- Jour. African Earth Sci. 15, 3/4, 473-487.

Saint-Marc P. (1992b) - Les foraminifères du Paléocène du sondage Ashtart Est-1 (Golfe de Gabès, Tunisie). Biostratigraphie et paléoenvironments.- Géol. Méditerranéenne 19, 1 , 31,39 . 